\title{
Aids Epidemic in Thailand: Good News, Bad News, and a Warning
}

\author{
Joseph Roberts \\ Visiting Researcher, Zunyi Medical College, Zhuhai, China \\ E-mail: editor@populationreview.cm
}

The AIDS epidemic has taken its toll in Thailand. Between 1985 and 2006, an estimated $1,102,628$ people (adults and children) were infected with HIV and 558,578 died of AIDS related complications (data from the Thailand A2 Team cited in AIDS Thailand, 2007). These numbers are large (one is too many). They represent a level of human tragedy and misery beyond measure. Nevertheless, Thailand's response to the AIDS epidemic has been one of the most successful in the world. Its no-nonsense, pragmatic approach to combating the disease prevented millions of new infections (Brown, 2003; UNDP, 2004). Because of past actions, reductions are now being seen in the number of people (adults and children) living with HIV, the number of adults (15+) living with HIV, the number of children (0-14) living with HIV, and the number of deaths of adults and children from AIDS (UNAIDS/WHO, 2006).

In addition, the number of new annual HIV infections in the general population continues to drop from its early 90s high (UNDP, 2004: 2; UNAIDS/WHO, 2006: 32). Moreover, rates of HIV infection among pregnant women have declined significantly from their highs in the mid90s (UNAIDS/WHO, 2006a:6; UNAIDS/WHO, 2004:2). There has been a reduction in motherto-child transmission of HIV (WHO, 2006). More good news: $75 \%$ of all HIV-infected pregnant women now receive AZT to prevent MTCT, virtually all children born to HIV-infected mothers receive drug treatment, and just over half of the 12,000 children needing antiretroviral therapy are currently receiving it (WHO, 2006).

Make no mistake, problems remain. Without

Address for correspondence: Dr. Joseph Roberts, Ph.D. Editor of Population Review and Consultant on Population and Development Programs and Policies Ste. 229 205/5 Moo 10 S. Pataya 2 Rd.

Nongprue Banglamung, Chonburi

Thailand 20260

E-mail: editor@populationreview.com proper vigilance and action the situation could turn for the worse. About $1.4 \%$ of adult (15-49) Thais are living with HIV (UNAIDS, 2006). 15,00020,000 Thais are becoming HIV positive each year (Thailand A2 Team, 2005). After dramatic declines from their highs in the early 90s, HIV sentinel surveillance prevalence rates for sex workers in major urban areas are showing signs of an increase: 2.6 in 2002, 3.6 in 2003, 4.3 in 2004 (UNAIDS/WHO, 2006a: 6). Prevalence rates among IDUs (injecting drug users) in and outside of major urban areas continue to be unacceptably high (UNAIDS/WHO, 2006a: 6). This fact, coupled with a "crackdown" on alleged drug dealers, is setting the stage for a new spread of the virus (cf. UNDP, 2004: 70). Some evidence indicates that the majority of drug injectors that purchase sex in Thailand use a condom (MAP, 2005: 9). But many do not. Consequently, the spread of the HIV virus from IDUs to the general population remains a serious threat.

Indicative of a upsurge in unprotected sex, STI (sexually transmitted infection) patients in major urban areas have increased sharply, from 5.1 in 2002 to 11.6 in 2004 (UNAIDS/WHO, 2006a:6). HIV prevalence among MSMs (males who have sex with males) in major urban areas remains very high (UNAIDS/WHO, 2006a: 7). The number of indirect sex workers is on the rise, making prevention efforts more difficult. The epidemic is shifting to mobile populations (e.g., migrant workers) that are hard to reach with intervention programs (UNDP, 2004: 70). A recent and disturbing trend is that a large percentage of new infections are occurring in people considered to be at low risk of infection. In 2004, 38\% of the reported cases were female (CDC online database). In $2005,43 \%$ of new infections occurred among the heterosexual population (Gouws et al., 2006). Heterosexuals, married women, and young people are increasingly becoming at risk of infection.

A persistent problem is that stigma and discrimination continue to undermine efforts to 
stop the epidemic in its tracks (UNDP, 2004: 71). With proper political leadership, attitudes could change. Unfortunately, political leadership on the HIV/AIDS issue has severely waned. Complacency has set in. In 2001, the Thai Working Group on HIV Projections sounded a prescient warning (2001: x): "Unless prevention efforts are sustained at a high level, the epidemic could quickly gain momentum and start to increase rapidly." Those words remain true.

\section{REFERENCES}

AIDS Thailand. 2007. AIDS Cluster, Bureau of AIDS, TB and STIs, Department of Diseases Control, Ministry of Public Health, Thailand [Available at http:// www.aidsthai.org/aidsenglish/situation_02.html]

Brown, T. 2003. Understanding HIV prevalence differentials in Southeast Asia. East-West Center and Thai Red Cross Society collaboration on HIV analysis, Modeling and Policy: Bangkok.

CDC (online database). The HHS/CDC Global AIDS Program in Thailand. Centers for Disease Control and Prevention (CDC): USA [Available at http:// www.cdc.gov/nchstp/od/gap/countries/thailand.htm, accessed February 2, 2007]

Gouws, E., et al. 2006. "Short term estimates of adult HIV incidence by mode of transmission: Kenya and Thailand as examples." Sexually Transmitted Infections, 82 (Suppl.3): iii 51-55.

MAP. 2005. Drug Injection and HIV/AIDS in Asia. Monitoring the AIDS Pandemic Network [Available at http://www.mapnetwork.org/docs/MAP_IDU\% 20Book\%2024Jun05_en.pdf]

Thailand A2 Team. 2005. A2: Reviving the Response Thailand. The Thailand A2 Team, East-West Center, Thai Red Cross Collaboration on Modeling,
Analysis and Policy. 7th International Conference on AIDS in Asia and the Pacific, Satellite Symposium, Kobe, Japan, July 2, 2005 [Available at http:// www2.eastwestcenter.org/pop/misc/presentation5.pdf]

Thai Working Group on HIV/AIDS Projection. 2001. Projections for HIV/AIDS in Thailand: $2000-2020$.

UNDP. 2004. Thailand's Response to HIV/AIDS: Progress and Challenges. Thematic MDG Report. United Nations Development Programme: Bangkok. (Available at http://www.synergyaids.com/documents/ UNDP_ThaiHIV_ProgConseq.pdf]

UNAIDS. 2006. 2006 Report on the global AIDS epidemic. Joint United Nations Programme on HIV/ AIDS: Geneva [Available at http://www.unaids.org/ en/HIV_data/2006GlobalReport/default.asp]

UNAIDS/WHO. 2004. Epidemiological fact sheets on HIV/AIDS and Sexually Transmitted Infections, 2004 Update. (Thailand). Joint United Nations Programme on HIV/AIDS (UNAIDS) and World Health Organization (WHO): Geneva [Available at http://www.searo.who.int/LinkFiles/Facts_and_ Figures Thailand_Epid.pdf]

UNAIDS/WHO. 2006. 2006 AIDS epidemic update. Global summary of the AIDS epidemic, December 20. Joint United Nations Programme on HIV/AIDS (UNAIDS) and World Health Organization (WHO). [Available at http://www.unaids.org/en/HIV_data/ epi2006/default.asp]

UNAIDS/WHO. 2006a. Epidemiological fact sheets on HIV/AIDS and Sexually Transmitted Infections, 2006 Update. (Thailand). Joint United Nations Programme on HIV/AIDS (UNAIDS) and World Health Organization (WHO): Geneva [Available at http:// www.who.int/GlobalAtlas/predefinedReports/ EFS2006/EFS_PDFs/EFS2006_TH.pdf]

WHO. 2006. "Taking stock: HIV in Children." In, HIV/ AIDS Programme: Strengthening health services to fight HIV/AIDS. World Health Organization: Geneva 